\title{
Regional Financial Performance Before and After The Regional Autonomy in Special Region of Yogyakarta
}

\author{
Djoko Susanto, Rudy Badrudin ${ }^{\bowtie}$, Nuri Marlia \\ STIE YKPN School of Business, Yogyakarta, Indonesia \\ e-mail: rudybadrudin.stieykpn@gmail.com
}

\begin{abstract}
The purpose of this study to examines and analyze differences the financial performance of local governments before and after decentralization. Through regional autonomy, local government has the authority to explore the role of the allocation of income and perform independently in setting development priorities. It is based on Law No. 23/2014 on Regional Government and Law No. 33/2004 on Financial Balance between Central and Local Government. The sample in this study were all districts in Special Region of Yogyakarta (DIY) in the period of 1994 to 2015. The sample used is districts in DIY namely Bantul, Gunungkidul, Kulon Progo, Sleman Regency, and Yogyakarta City. Data used in this research is secondary data. Data analysis using Paired Sample T-Test. These results indicate that there is no difference of fiscal decentralization degrees in districts in DIY before and after regional autonomy; there is no difference of regional financial independence ratio in districts in DIY before and after regional autonomy; and there is differences of regional financial in harmony ratio in districts in DIY before and after regional autonomy.
\end{abstract}

Keywords: regional autonomy, regional financial performance

\begin{abstract}
Abstrak
Tujuan penelitian ini untuk menguji dan menganalisis perbedaan kinerja keuangan pemerintah daerah sebelum dan sesudah desentralisasi. Melalui otonomi daerah, pemerintah daerah memiliki kewenangan untuk mengeksplorasi peran alokasi pendapatan dan melakukan secara mandiri dalam menetapkan prioritas pembangunan. Hal ini didasarkan pada UU No. 23/2014 tentang Pemerintahan Daerah dan UU No. 33/2004 tentang Perimbangan Keuangan antara Pemerintah Pusat dan Pemerintah Daerah. Sampel dalam penelitian ini adalah seluruh kabupaten di Daerah Istimewa Yogyakarta (DIY) pada periode 1994 hingga 2015. Sampel yang digunakan adalah kabupaten di DIY yaitu Bantul, Gunungkidul, Kulon Progo, Kabupaten Sleman, dan Kota Yogyakarta. Data yang digunakan dalam penelitian ini adalah data sekunder. Analisis data menggunakan Paired Sample T - Test. Hasil penelitian menunjukkan bahwa tidak ada perbedaan tingkat desentralisasi fiskal di kabupaten di DIY sebelum dan sesudah otonomi daerah; tidak ada perbedaan rasio kemandirian keuangan daerah di kabupaten-kabupaten di DIY sebelum dan sesudah otonomi daerah; dan ada perbedaan rasio keuangan daerah dalam keselarasan di kabupaten di DIY sebelum dan sesudah otonomi daerah.
\end{abstract}

Kata kunci: otonomi daerah, kinerja keuangan daerah 


\section{INTRODUCTION}

Regional autonomy is a form of delivery system of government affairs and delegation of authority to regions from central to local government. Regional autonomy is defined as the right, authority, and obligation of the autonomous regions to regulate and manage their own governmental affairs and the interests of the local community in accordance with the laws and regulations. Based on Law Number 23/2014 on Regional Government, decentralization is defined as the transfer of government authority by the Government to the Autonomous Region within the framework of the Unitary State of the Republic of Indonesia.

Through regional autonomy, local governments have the authority to generate revenue and perform independent allocation roles in setting development priorities. The objectives of regional autonomy are to help increase the national allocation and operational efficiency of local governments and meet regional aspirations; improve overall fiscal structure and mobilize regional and national revenues; improve accountability, transparency, and develop constituent participation in decision-making at the local level; reducing fiscal gaps among local governments, ensuring the implementation of basic community services across Indonesia, and promoting government efficiency goals; and improve the social welfare of the Indonesian people.

Through regional autonomy, the central government hopes the regions will be more independent in determining all their activities and the central government is expected to be less dominant in regulating the regions. According to Badrudin (2011), the regional government is expected to play its role in opening opportunities to promote the region by identifying the potential sources of income and able to determine regional spending economically, reasonably, efficiently and effectively including regional apparatus in improving performance and accountability to public based on legislation. The policy of regional autonomy as stipulated in Law Number 23/2014 on Regional Government is expected to give more opportunity to the change of democratic regional government which will ultimately improve the prosperity of the people as a whole.

The implementation of regional autonomy, public accountability is a key word. In the context of government organizations, public accountability is the provision of information and disclosure of government financial activities and performance to the parties concerned with the report. Demands for accountability in the public sector are linked to the need for transparency and information to the public. Central and local governments, should be the subject of the information giver in the context of the fulfillment of public rights. Public sector financial reports are an important part of the public accountability process. To support the implementation of public fund management based on the concept of value for money, it is necessary to have local financial management system and local budget oriented on performance. This is to support the creation of public accountability of local governments in the context of regional autonomy.

Orientation of public sector development to create good governance. Good governance is the implementation of solid and responsible development management that is consistent with democratic and efficient market principles, preventing corruption both politically and administratively, running budget discipline, and creating legal and political framework for growing business activities. Regional financial management that is carried out economically, efficiently, and effectively, and fulfilling the principles of value for money and participatory, 
transparency, accountability and justice can encourage economic growth and independence of a region. Thus, regions with good financial performance mean that the region has the financial capacity to finance the implementation of regional autonomy. The level of financial capacity of the region one of which can be measured from the amount of regional revenue, especially local revenue. The efforts of local government in exploring the financial capacity of the regions can be seen from the performance of regional financial measured using the analysis of local government financial ratios include the degree of fiscal decentralization, the ratio of local financial independence, and regional compatibility ratio (Rasidah \& Marsidah, 2009).

The Special Region of Yogyakarta (DIY) as an autonomous region as part of the Unitary State of the Republic of Indonesia has the right and authority to govern and manage its own territory. Regions will be encouraged to explore the potential of the region and find sources of revenue and spending that can improve the welfare of the community. The regional revenue and spending in four regencies of Bantul, Gunungkidul, Kulon Progo, Sleman Regency and one city of Yogyakarta City in the period of 1994 to 2015 have changed. Thus, various measures of financial performance are also changing. The change was caused by the enactment of regional autonomy as of January 1, 2001. Based on the description, the authors are interested to examine the financial performance of regions before and after regional autonomy in districts in DIY.

The objectives of the study were to examine and analyze whether there is an average differences of fiscal decentralization degrees, differences of regional financial independence ratio, and differences of regional financial in harmony ratio in districts in DIY before and after regional autonomy. Benefits of the study for the development of theory about the performance of regional finances, inputs to local governments in improving local financial performance in the future, and a reference in decision-making related to regional finance.

According to Regulation of the Minister of Home Affairs (Permendagri) No.13/2006 article 1, performance is the outcome of programs that will or has been achieved in relation to the use of budgets with quantity and quality measured. Performance is a description of the level of achievement of the implementation of a program in realizing the goals, mission and vision of the organization contained in the stratetgic planning organization. Financial performance is a measure of performance using financial indicators. Performance measurement is used as a tool for organizational oversight and evaluation. Performance measurement results are used as feedback for the following year in both planning and implementation.

According to Taufik, Darwanis, and Arfan (2014), the financial performance of district governments in Darussalam Aceh Nangro Province at the time of fair opinion with exceptions is no different from the local government'sfinancialperformanceatthetime of Unqualified Opinion. Study of Dwijayanti \& Rusherlistyanti (2013) showed that 1) there is a significant degree of independence on the financial performance; 2) there is a significant difference in effectiveness level on the government's financial performance; 3) there is no significant difference in efficiency level in the government's financial performance; 4) there is a difference in the level of routine spending activities and significant development spending on the government's financial performance; 5) there is no significant difference in the rate of growth of local own source revenue (PAD) on the financial performance; 6 ) there is no significant difference in the level of regional revenue growth in the government's financial performance; 7) there is no significant 
difference in growth rate of routine spending on the government's financial performance; and 8) there is no significant difference in growth rate of development spending on the financial performance of all provincial governments in Indonesia for 2008-2010.

Study of Badrudin (2012) showed that there is a difference in average contribution of Gross Regional Domestic Product (low and high) value between regencies/cities in Central Java Province and there is difference in average growth rate of Gross Regional Domestic Product (low and high) value between regencies/cities in Central Java Province. Wardana and Nasikh (2013) explained that 1) the fiscal decentralization degree of Malang City before the existence of regional autonomy policy is still low. This means that the percentage of local revenues to total regional revenues is relatively small when compared to the central government's balance funds; 2) the fiscal decentralization degree of Malang City after the existence of regional autonomy policy is still relatively low. This means that the percentage of local revenues to total regional revenues is still relatively small when compared with the central government's balance funds; 3 ) the financial performance of Malang City is seen from the comparison of the fiscal decentralization degree before the existence of regional autonomy policy is better when compared with after the regional autonomy. This is seen from the fiscal decentralization degree. The average value of fiscal decentralization degree before regional autonomy is $33 \%$ while the average value of fiscal decentralization degree after regional autonomy is $12.5 \%$.

According to Aryanto (2011), the financial independence of regencies/cities in South Sumatra Province is included in very low category. The average value of the highest ratio of local financial independence is only $17.28 \%$, namely in Palembang City, and the second highest is Lubuk Linggau with regional financial independence ratio of 6.94\%. Study of Mustafa and Halim (2009) explained that the measurement of revenue performance in West Kalimantan Province resulted in good performance in managing PAD sources. Sularso and Restianto (2011) explained that one factor that affects indirect economic growth is the performance of local financials. Study of Adi (2012) showed that in general the region experienced an increase in economic growth and revenue growth of indigenous PAD areas. Enceng, Irianro, and Purwaningdyah (2012) explained that the fiscal decentralization degree and financial independence of Purworejo Regency is still very low. Study of Azhar (2012) explained that there is no difference in financial performance in the form of fiscal decentralization degree and there is no difference in financial performance in the form of budgetary efficiency in the era before and after regional autonomy.

Based on the explanation, then prepared the research hypothesis as follows:

H1: There is an average difference of fiscal decentralization degrees in districts in DIY before and after regional autonomy.

$\mathrm{H} 2$ : There is an average difference of regional financial independence ratio in districts in DIY before and after regional autonomy.

H3: There is an average difference of regional financial in harmony ratio in districts in DIY before and after regional autonomy. 


\section{METHOD}

This study is done by comparing the report of budget realization of each regency/ city in DIY. The Regional GovernmentBudget (APBD) that are compared are realized from APBD before (1994-2000) and after (20012015) regional autonomy. The population of this study is the districts in DIY by using data collection methods by purposive sampling. The selected samples are districts which since the enactment of existing autonomy that are Bantul, Gunungkidul, Kulon Progo, Sleman Regency, and Yogyakarta City.

The fiscal decentralization degrees shows the independence of regional finance which is seen from the components of financial data that is local revenue, tax sharing and non taxes. This ratio shows the independence of local governments in financing the needs of their regions without relying on the central government. According to Mahmudi (2010: 142), the fiscal decentralization degrees is measured by comparing local revenue, tax sharing and non-taxes with total regional spendings. The fiscal decentralization degree variable is measured by the percent unit (\%). According to Mahmudi (2010: 142), the regional financial independence ratio demonstrates the ability of local governments to finance government, development and service activities to communities who have paid taxes and levies as a necessary source of income. The regional financial independence ratio is indicated by the ratio between the own source revenue and the local revenue. The higher of regional financial independence ratio, the higher the public participation in paying taxes and levies. The regional financial independence ratio is measured by comparing the own source revenue to local revenue. Variable of regional financial independence ratio is measured by unit percent (\%). According to Mahmudi (2010:162), the regional financial in harmony ratio illustrates how local governments prioritize the allocation of funds to routine spending and development spending optimally. The higher the percentage of funds allocated for routine spending means that the percentage of development spending used to provide economic facilities and infrastructure tends to be smaller. The regional financial in harmony ratio is measured by comparing routine spending to total spending or between public spending to total spending. Variable of regional financial in harmony ratio is measured by percentage (\%). Data analysis method used to test the hypothesis is paired sample t-test method using SPSS software.

\section{RESULTS AND DISCUSSION}

The fiscal decentralization degrees shows the independence of regional finance which is seen from the components of financial data that is local revenue, tax sharing and non taxes. This ratio shows the independence of local governments in financing the needs of their regions without relying on the central government. The following is presented data on the fiscal decentralization degrees in Table 1. 
Table 1. Fiscal Decentralization Degrees in Districts in DIY, 1994-2015

\begin{tabular}{cccccc}
\hline Year & Bantul & Gunungkidul & Kulon Progo & Sleman & Yogyakarta \\
\hline 1994 & $31.02 \%$ & $28.28 \%$ & $30.96 \%$ & $35.40 \%$ & $53.67 \%$ \\
1995 & $34.08 \%$ & $30.62 \%$ & $31.34 \%$ & $37.71 \%$ & $50.68 \%$ \\
1996 & $32.10 \%$ & $30.85 \%$ & $32.11 \%$ & $24.20 \%$ & $54.21 \%$ \\
1997 & $27.81 \%$ & $25.93 \%$ & $28.56 \%$ & $23.26 \%$ & $50.45 \%$ \\
1998 & $67.15 \%$ & $16.53 \%$ & $15.47 \%$ & $17.51 \%$ & $22.78 \%$ \\
1999 & $15.45 \%$ & $13.18 \%$ & $14.86 \%$ & $21.77 \%$ & $36.27 \%$ \\
2000 & $10.89 \%$ & $8.58 \%$ & $12.15 \%$ & $18.26 \%$ & $22.62 \%$ \\
2001 & $9.37 \%$ & $8.27 \%$ & $7.74 \%$ & $16.42 \%$ & $32.36 \%$ \\
2002 & $10.51 \%$ & $9.09 \%$ & $10.01 \%$ & $15.96 \%$ & $26.89 \%$ \\
2003 & $12.84 \%$ & $8.52 \%$ & $11.83 \%$ & $18.14 \%$ & $29.80 \%$ \\
2004 & $12.78 \%$ & $10.19 \%$ & $10.98 \%$ & $20.50 \%$ & $31.87 \%$ \\
2005 & $14.15 \%$ & $11.33 \%$ & $12.41 \%$ & $23.93 \%$ & $32.83 \%$ \\
2006 & $11.01 \%$ & $9.54 \%$ & $11.83 \%$ & $19.95 \%$ & $26.31 \%$ \\
2007 & $10.00 \%$ & $8.71 \%$ & $11.40 \%$ & $10.00 \%$ & $10.00 \%$ \\
2008 & $10.59 \%$ & $8.58 \%$ & $11.18 \%$ & $24.93 \%$ & $26.89 \%$ \\
2009 & $15.08 \%$ & $9.56 \%$ & $10.76 \%$ & $25.21 \%$ & $30.40 \%$ \\
2010 & $13.80 \%$ & $9.69 \%$ & $12.71 \%$ & $24.65 \%$ & $31.27 \%$ \\
2011 & $14.83 \%$ & $9.35 \%$ & $10.56 \%$ & $23.34 \%$ & $30.64 \%$ \\
2012 & $16.50 \%$ & $10.07 \%$ & $12.46 \%$ & $25.16 \%$ & $34.35 \%$ \\
2013 & $17.06 \%$ & $10.26 \%$ & $13.26 \%$ & $25.18 \%$ & $35.83 \%$ \\
2014 & $17.65 \%$ & $10.45 \%$ & $14.11 \%$ & $25.20 \%$ & $37.38 \%$ \\
2015 & $18.25 \%$ & $10.64 \%$ & $15.01 \%$ & $25.23 \%$ & $39.00 \%$ \\
\hline & & $50 \%$ & & &
\end{tabular}

Source: www.kemenkeu.go.id., data processed

Based on Table 1, it appears that the fiscal decentralization degrees of city is higher than of regency. That is, city are better able to manage finances than regencies. The fiscal decentralization degrees from 1994 to 2015 for all districts in DIY tends to decline. Among regencies in DIY, it appears that
Sleman Regency has the largest average of the fiscal decentralization degrees.

The regional financial independence ratio is indicated by the ratio between the own source revenue and the local revenue. The following is presented data on the regional financial independence ratio in Table 2. 
Regional Financial Performance Before and After ... (Djoko Susanto, Rudy Badrudin, Nuri Marlia)

Table 2. Regional Financial Independence Ratio in Districts in DIY, 1994-2015

\begin{tabular}{cccccc}
\hline Year & Bantul & Gunungkidul & Kulon Progo & Sleman & Yogyakarta \\
\hline 1994 & $15.58 \%$ & $10.61 \%$ & $12.25 \%$ & $19.77 \%$ & $37.41 \%$ \\
1995 & $17.24 \%$ & $11.95 \%$ & $11.75 \%$ & $22.69 \%$ & $35.25 \%$ \\
1996 & $15.69 \%$ & $11.67 \%$ & $13.70 \%$ & $14.68 \%$ & $38.28 \%$ \\
1997 & $13.73 \%$ & $9.30 \%$ & $12.98 \%$ & $14.92 \%$ & $35.48 \%$ \\
1998 & $47.11 \%$ & $9.02 \%$ & $6.90 \%$ & $9.88 \%$ & $14.91 \%$ \\
1999 & $8.49 \%$ & $6.24 \%$ & $8.22 \%$ & $13.57 \%$ & $25.42 \%$ \\
2000 & $6.56 \%$ & $5.00 \%$ & $7.27 \%$ & $12.90 \%$ & $17.42 \%$ \\
2001 & $5.26 \%$ & $4.28 \%$ & $4.58 \%$ & $9.58 \%$ & $17.78 \%$ \\
2002 & $6.66 \%$ & $5.36 \%$ & $6.45 \%$ & $9.83 \%$ & $18.61 \%$ \\
2003 & $8.44 \%$ & $5.11 \%$ & $8.17 \%$ & $11.70 \%$ & $20.26 \%$ \\
2004 & $7.72 \%$ & $5.79 \%$ & $6.69 \%$ & $12.49 \%$ & $21.62 \%$ \\
2005 & $8.52 \%$ & $6.89 \%$ & $7.91 \%$ & $14.97 \%$ & $22.76 \%$ \\
2006 & $7.34 \%$ & $5.65 \%$ & $7.85 \%$ & $12.90 \%$ & $18.58 \%$ \\
2007 & $10.00 \%$ & $4.79 \%$ & $7.39 \%$ & $10.00 \%$ & $10.00 \%$ \\
2008 & $6.82 \%$ & $4.78 \%$ & $7.27 \%$ & $15.94 \%$ & $18.39 \%$ \\
2009 & $10.05 \%$ & $5.40 \%$ & $6.60 \%$ & $15.78 \%$ & $21.53 \%$ \\
2010 & $8.27 \%$ & $5.33 \%$ & $7.63 \%$ & $14.88 \%$ & $22.00 \%$ \\
2011 & $10.92 \%$ & $5.64 \%$ & $6.79 \%$ & $17.29 \%$ & $24.05 \%$ \\
2012 & $12.46 \%$ & $6.23 \%$ & $8.39 \%$ & $18.94 \%$ & $29.22 \%$ \\
2013 & $13.64 \%$ & $6.54 \%$ & $9.18 \%$ & $20.20 \%$ & $32.43 \%$ \\
2014 & $14.93 \%$ & $6.87 \%$ & $10.04 \%$ & $21.55 \%$ & $36.00 \%$ \\
2015 & $16.35 \%$ & $7.21 \%$ & $10.98 \%$ & $22.99 \%$ & $39.96 \%$ \\
\hline
\end{tabular}

Source: www.kemenkeu.go.id., data processed

Based on Table 2, it appears that the regional financial independence ratio of city is higher than of regency. That is, city are better able to manage finances than regency. The regional financial independence ratio from 1994 to 2015 for all districts in DIY tends to be stable. Among regencies in DIY, it appears that Sleman Regency has the largest average of the regional financial independence ratio.
The regional financial in harmony ratio illustrates how local governments prioritize the allocation of funds to routine spending and development spending optimally. The following is presented data on the regional financial in harmony ratio base on the routine spending in Table 3a. 
Table 3a. Regional Financial in Harmony Ratio in Districts in DIY (Routine Spending), 1994-2015

\begin{tabular}{|c|c|c|c|c|c|}
\hline Year & Bantul & Gunungkidul & Kulon Progo & Sleman & Yogyakarta \\
\hline 1994 & $58.93 \%$ & $56.61 \%$ & $46.30 \%$ & $54.29 \%$ & $31.58 \%$ \\
\hline 1995 & $55.68 \%$ & $50.67 \%$ & $48.06 \%$ & $57.20 \%$ & $46.10 \%$ \\
\hline 1996 & $61.00 \%$ & $51.61 \%$ & $51.76 \%$ & $29.26 \%$ & $46.46 \%$ \\
\hline 1997 & $43.37 \%$ & $44.94 \%$ & $40.37 \%$ & $29.59 \%$ & $36.03 \%$ \\
\hline 1998 & $21.06 \%$ & $22.83 \%$ & $24.99 \%$ & $23.78 \%$ & $24.02 \%$ \\
\hline 1999 & $22.75 \%$ & $27.37 \%$ & $22.42 \%$ & $22.44 \%$ & $27.12 \%$ \\
\hline 2000 & $27.27 \%$ & $38.45 \%$ & $21.33 \%$ & $22.37 \%$ & $24.01 \%$ \\
\hline 2001 & $12.12 \%$ & $19.99 \%$ & $27.58 \%$ & $13.02 \%$ & $8.55 \%$ \\
\hline 2002 & $17.47 \%$ & $17.74 \%$ & $26.08 \%$ & $8.47 \%$ & $15.12 \%$ \\
\hline 2003 & $10.84 \%$ & $22.35 \%$ & $14.46 \%$ & $18.38 \%$ & $20.81 \%$ \\
\hline 2004 & $10.89 \%$ & $12.37 \%$ & $9.64 \%$ & $17.30 \%$ & $18.15 \%$ \\
\hline 2005 & $9.02 \%$ & $9.07 \%$ & $4.85 \%$ & $15.84 \%$ & $19.92 \%$ \\
\hline 2006 & $14.23 \%$ & $25.18 \%$ & $18.27 \%$ & $13.60 \%$ & $18.57 \%$ \\
\hline 2007 & $15.63 \%$ & $21.60 \%$ & $19.94 \%$ & $15.12 \%$ & $15.82 \%$ \\
\hline 2008 & $29.11 \%$ & $23.47 \%$ & $19.32 \%$ & $11.20 \%$ & $20.53 \%$ \\
\hline 2009 & $11.94 \%$ & $14.41 \%$ & $8.40 \%$ & $14.70 \%$ & $11.09 \%$ \\
\hline 2010 & $12.24 \%$ & $6.51 \%$ & $7.63 \%$ & $9.17 \%$ & $6.44 \%$ \\
\hline 2011 & $12.75 \%$ & $13.91 \%$ & $13.58 \%$ & $7.76 \%$ & $8.87 \%$ \\
\hline 2012 & $10.94 \%$ & $16.05 \%$ & $16.84 \%$ & $9.64 \%$ & $8.63 \%$ \\
\hline 2013 & $10.67 \%$ & $20.02 \%$ & $22.05 \%$ & $8.72 \%$ & $8.43 \%$ \\
\hline 2014 & $10.40 \%$ & $24.98 \%$ & $28.87 \%$ & $7.88 \%$ & $8.24 \%$ \\
\hline 2015 & $10.14 \%$ & $31.16 \%$ & $37.81 \%$ & $7.12 \%$ & $8.05 \%$ \\
\hline
\end{tabular}

Source: www.kemenkeu.go.id, data processed

Based on Table 3a, it appears that the regional financial in harmony ratio based on regency routine spending is higher than of city. That is, the regency government allocates more spending to the needs of the regional apparatus than for public spending compared to the city government. The regional financial in harmony ratio from
1994 to 2015 for all districts in DIY tended to decline. Among regencies in DIY, it appears that Gunungkidul Regency has the largest average of the regional financial in harmony ratio of routine spending.

The following is presented data on the regional financial in harmony ratio base on the public spending in Table $3 \mathrm{~b}$. 
Regional Financial Performance Before and After ... (Djoko Susanto, Rudy Badrudin, Nuri Marlia)

Table 3b. Regional Financial in Harmony Ratio in Districts in DIY (Public Spending), 1994-2015

\begin{tabular}{|c|c|c|c|c|c|}
\hline Year & Bantul & Gunungkidul & Kulon Progo & Sleman & Yogyakarta \\
\hline 1994 & $41.07 \%$ & $43.39 \%$ & $53.70 \%$ & $45.71 \%$ & $68.42 \%$ \\
\hline 1995 & $44.32 \%$ & $49.33 \%$ & $51.94 \%$ & $42.80 \%$ & $53.90 \%$ \\
\hline 1996 & $39.00 \%$ & $48.39 \%$ & $48.24 \%$ & $70.74 \%$ & $53.54 \%$ \\
\hline 1997 & $56.63 \%$ & $55.06 \%$ & $59.63 \%$ & $70.41 \%$ & $63.97 \%$ \\
\hline 1998 & $78.94 \%$ & $77.17 \%$ & $75.01 \%$ & $76.22 \%$ & $75.98 \%$ \\
\hline 1999 & $77.25 \%$ & $72.63 \%$ & $77.58 \%$ & $77.56 \%$ & $72.88 \%$ \\
\hline 2000 & $72.73 \%$ & $61.55 \%$ & $78.67 \%$ & $77.63 \%$ & $75.99 \%$ \\
\hline 2001 & $87.88 \%$ & $80.01 \%$ & $72.42 \%$ & $86.98 \%$ & $91.45 \%$ \\
\hline 2002 & $82.53 \%$ & $82.26 \%$ & $73.92 \%$ & $91.53 \%$ & $84.88 \%$ \\
\hline 2003 & $89.16 \%$ & $77.65 \%$ & $85.54 \%$ & $81.62 \%$ & $79.19 \%$ \\
\hline 2004 & $89.11 \%$ & $87.63 \%$ & $90.36 \%$ & $82.70 \%$ & $81.85 \%$ \\
\hline 2005 & $90.98 \%$ & $90.93 \%$ & $95.15 \%$ & $84.16 \%$ & $80.08 \%$ \\
\hline 2006 & $85.77 \%$ & $74.82 \%$ & $81.73 \%$ & $86.40 \%$ & $81.43 \%$ \\
\hline 2007 & $84.37 \%$ & $78.40 \%$ & $80.06 \%$ & $84.88 \%$ & $84.18 \%$ \\
\hline 2008 & $70.89 \%$ & $76.53 \%$ & $80.68 \%$ & $88.80 \%$ & $79.47 \%$ \\
\hline 2009 & $88.06 \%$ & $85.59 \%$ & $91.60 \%$ & $85.30 \%$ & $88.91 \%$ \\
\hline 2010 & $87.76 \%$ & $93.49 \%$ & $92.37 \%$ & $90.83 \%$ & $93.56 \%$ \\
\hline 2011 & $87.25 \%$ & $86.09 \%$ & $86.42 \%$ & $92.24 \%$ & $91.13 \%$ \\
\hline 2012 & $89.06 \%$ & $83.95 \%$ & $83.16 \%$ & $90.36 \%$ & $91.37 \%$ \\
\hline 2013 & $89.33 \%$ & $79.98 \%$ & $77.95 \%$ & $91.28 \%$ & $91.57 \%$ \\
\hline 2014 & $89.60 \%$ & $75.02 \%$ & $71.13 \%$ & $92.12 \%$ & $91.76 \%$ \\
\hline 2015 & $89.86 \%$ & $68.84 \%$ & $62.19 \%$ & $92.88 \%$ & $91.95 \%$ \\
\hline
\end{tabular}

Source: www.kemenkeu.go.id, data processed

Based on Table 3b, it appears that the regional financial in harmony ratio based on city public spending is higher than of regency. That is, the city government allocates more spending to the needs of public spending than for routine spending compared to the regency government. The regional financial in harmony ratio from 1994 to 2015 for all districts in DIY tended to increase. Among regencies in DIY, it appears that Sleman Regency has the largest average of the regional financial in harmony ratio of public spending.

Data analysis based on descriptive statistical results is shown in Table 4 below. 
Table 4. Descriptive Statistics of Regional Financial Ratios

\begin{tabular}{lccc}
\hline Financial Ratio & Minimum & Maximum & Mean \\
\hline DDFB & $22.00 \%$ & $41.52 \%$ & $28.76 \%$ \\
DDFA & $9.41 \%$ & $36.13 \%$ & $21.00 \%$ \\
RKKDB & $9.11 \%$ & $29.17 \%$ & $16.28 \%$ \\
RKKDA & $5.44 \%$ & $27.90 \%$ & $15.54 \%$ \\
RKDBRB & $58.22 \%$ & $66.38 \%$ & $62.51 \%$ \\
RKDBRA & $83.54 \%$ & $87.64 \%$ & $85.82 \%$ \\
RKDBPB & $33.62 \%$ & $41.78 \%$ & $37.49 \%$ \\
RKDBPA & $12.36 \%$ & $16.46 \%$ & $14.18 \%$ \\
\hline
\end{tabular}

Source: Table 1, 2, and 3, data processed

Note:

DDFB: fiscal decentralization degree before regional autonomy DDFA: fiscal decentralization degree after regional autonomy RKKDB: regional financial independence ratio before regional autonomy

RKKDA: regional financial independence ratio after regional autonomy

RKDBRB: regional financial in harmony ratio (routine spending) before regional autonomy

RKDBRA: regional financial in harmony ratio (routine spending) after regional autonomy

RKDBPB: regional financial in harmony ratio (development spending) before regional autonomy

RKDBPA: regional financial in harmony ratio (development spending) after regional autonomy

Based on Table 4, it appears that the minimum value of DDFB occurs in Gunungkidul Regency which is $22.00 \%$ while the maximum value occurs in Yogyakarta City which is $41.52 \%$. The minimum value of DDFA occurs in Gunungkidul Regency which is $9.41 \%$ while the maximum value occurs in Yogyakarta City which is $36.13 \%$. The average value of DDFB (28.76\%) is greater than DDFA $(21.00 \%)$.

The minimum value of RKKDB occurs in Gunungkidul Regency that is equal to $9.11 \%$ while the maximum value occurs in Yogyakarta City that is equal to $29.17 \%$. The minimum value of RKKDA occurs in Gunungkidul Regency which is $5.44 \%$ while the maximum value occurs in Yogyakarta City which is $27.90 \%$. The average value of RKKDB (16.28\%) is greater than RKKDA $(15.54 \%)$.

The minimum value of RKDBRB occurs in Gunungkidul Regency which is
$58.22 \%$ while the maximum value occurs in Yogyakarta City which is $66.38 \%$. The minimum value of RKDBRA occurs in Gunungkidul Regency which is $83.54 \%$ while the maximum value occurs in Bantul Regency which is $87.64 \%$. The average value of RKDBRB (62.51\%) is smaller than RKDBRA (85.82\%).

The minimum value of RKDBPB occurs in Yogyakarta City which is $33.62 \%$ while the maximum value occurs in Gunungkidul Regency which is $41.78 \%$. The minimum value of RKDBPA occurs in Sleman Regency which is $12.36 \%$ while the maximum value occurs in Bantul Regency which is $16.46 \%$. The average value of RKDBPB (37.48\%) is greater than RKDBPA (14.18\%).

Hypothesis testing is done by testing paired sample t-test. But before doing the test the author first to test the normality. Normality test is required as a prerequisite of the different test of two paired samples in this study using Kolmogorov Smirnov Test.

Table 5. The Result of Kolmogorov Smirnov Test

\begin{tabular}{lc}
\hline \multicolumn{1}{c}{ Financial Rasio } & Sig. \\
\hline DDFB & $\left({ }^{*} 0.882\right.$ \\
DDFA & $\left({ }^{*} 0,982\right.$ \\
RKKDB & $\left({ }^{*} 0,900\right.$ \\
RKKDA & $\left({ }^{*} 0,977\right.$ \\
RKDBRB & $\left({ }^{*} 0,928\right.$ \\
RKDBRA & $\left({ }^{*} 0,974\right.$ \\
RKDBPB & $\left({ }^{*} 0,928\right.$ \\
RKDBPA & $\left({ }^{*} 0,974\right.$ \\
\hline
\end{tabular}

Source: obtained from data processing *) significant because the value $\mathrm{p}$-value $>5 \%$, data is normally distributed

Based on the normality test results (Table 5) conducted for each performance ratio that is the fiscal decentralization degree, the regional financial independence ratio, and the regional financial in harmony ratio obtained results with a significance value above 0.05 . This means the data is normally distributed so that further testing with paired sample $\mathrm{t}$ test can be done. 
Regional Financial Performance Before and After ... (Djoko Susanto, Rudy Badrudin, Nuri Marlia)

The paired sample $t$ test results for each regional financial performance ratio tested are presented in detail in Table 6 below:

Table 6. The Results of Hypothesis Testing

\begin{tabular}{lcl}
\hline $\begin{array}{c}\text { Before and After of } \\
\text { Regional Autonomy }\end{array}$ & Sig. & Result \\
\hline DDFB-DDFA & 0.057 & H1 is rejected \\
RKKDB-RKKDA & 0.686 & H2 is rejected \\
RKDBRB-RKDBRA & 0.000 & $(* \mathrm{H} 3$ is supported \\
RKDBPB-RKDBPA & 0.000 & $(* \mathrm{H} 3$ is supported \\
\hline
\end{tabular}

Source: obtained from data processing

*) significant because the value $p$-value $\leq 5 \%$

Based on Table 6, the significance value of the test results of 0.057 is greater than the alpha (5\%). Therefore, the first hypothesis is rejected, meaning that there is not an average difference in fiscal decentralization degree in regencies/city in DIY before and after regional autonomy. This mean that the local government in financing the needs of the region is still dependent on the central government. Regional needs should be sufficient with PAD. But the facts show that PAD is still not optimal to be able to meet the needs of the region. This can happen because the local government has not been optimal in exploring the resources owned. Implementation of autonomy requires that each region must be able to finance its needs through its financial resources under its control to further reduce the dependence of the central government. The role of local government is very big in exploring and developing various potentials of the region as a source of local revenue. In addition, the relatively small tax revenue and non-tax revenues are not able to meet the needs of large areas. Based on the average of fiscal decentralization degree in DIY prior to regional autonomy was $28.76 \%$ while after regional autonomy actually decreased to $21.00 \%$. This shows that the performance of local government has decreased after regional autonomy. The results support the study of Enceng et al. (2012), Azhar (2012),
Wardana and Nasikh (2013), and Taufik et al. (2014) but not in accordance with the findings of Badrudin (2012), Adi (2012), and Dwijayanti and Rusherlistyanti (2013).

Based on Table 6, the significance value of the test results of 0.686 is greater than the alpha $(5 \%)$. Therefore, the second hypothesis is rejected, meaning that there is not an average difference in regional financial independence ratio in regencies/city in DIY before and after regional autonomy. The aspect of regional finance is one of the foundations to determine the ability of local governments in managing their finances independently, namely the extent to which local governments explore and develop various regional potentials as a source of local revenue to finance local financial needs. The districts own source revenue (PAD) as a part of regional income derived from the region is still relatively low. This shows that the area is still not optimal in exploring the potential of the existing area.

Table 7. The Regional Financial Capacity Scale

\begin{tabular}{cc}
\hline Range of Percentage & Financial Capacity \\
\hline $10.00-0.00$ & Very Less \\
$20.00-10.01$ & Less \\
$30.00-20.01$ & Enough \\
$40.00-30.01$ & Medium \\
$50.00-40.01$ & Good \\
$50.00<$ & Very Good \\
\hline
\end{tabular}

Source: Tangkilisan (2005:82)

The average value of the regional financial independence ratio in DIY after regional autonomy actually decreased from $16.40 \%$ to $15.54 \%$ compared to before regional autonomy. Based on Table 7 on the regional financial capacity scale, the value of the regional financial independence ratio in regencies/city in DIY is located in the less range. The results support the study of Aryanto (2011), Enceng et al. (2012), Azhar (2012), Dwijayanti and Rusherlistyanti (2013), Wardana and Nasikh (2013), and 
Taufik et al. (2014), but not in accordance with the findings of Adi (2012), Badrudin (2012), and Dwijayanti and Rusherlistyanti (2013).

Based on Table 6, the significance value of the test results of 0.000 is lower than the alpha (5\%). Therefore, the third hypothesis is supported, meaning that there is an average difference in regional financial in harmony ratio (routine spending) in regencies/city in DIY before and after regional autonomy. Based on Table 6, the significance value of the test results of 0.000 is lower than the alpha (5\%). Therefore, the third hypothesis is supported, meaning that there is difference in regional financial in harmony ratio (development spending) in regencies/city in DIY before and after regional autonomy.

The proportion of spending in APBD before and after the regional autonomy changes. The proportion of routine spending increases and development spending declines (Table 5). This indicates that local governments have not been able to manage regional spending. Within the framework of regional autonomy policy, the effectiveness of regional spending can be one of the main benchmarks for the successful implementation of regional autonomy itself. This indicates the extent to which regional autonomy policies implemented by local governments are able to encourage the achievement of national objectives, namely improving the social welfare and public services in the regions. Based on this, local governments should focus more on more productive development budgets.

This study shows that the condition is not ideal from the implementation of regional autonomy. As it is known that regional autonomy is the authority of the autonomous regions to regulate and manage the interests of local people according to their own initiative based on the aspirations of the people in accordance with the laws and regulations. Local governments are required to be able to manage their regional spending in order to be able to achieve an appropriate allocation of aspirations and needs of local communities. The results support the study of Dwijayanti \& Rusherlistyanti (2013).

\section{CONCLUSION}

Based on the findings and discussion, it is concluded that there is not an average differences of fiscal decentralization degrees and not an average differences of regional financial independence ratio, but there is an average differences of regional financial in harmony ratio in districts in DIY before and after regional autonomy. Based on the findings, the city are better able to manage finances than regencies in DIY. Among the regencies in DIY, it appears that Sleman Regency has the largest average of all regional financial performance indicators, except for the value of regional financial ratios in harmony (routine spending) because the greatest value is Gunungkidul Regency.

The average value of fiscal decentralization degree before regional autonomyis greaterthanfiscaldecentralization degree after regional autonomy, the average of regional financial independence ratio before regional autonomy is greater than the average of regional financial independence ratio after regional autonomy, the average of regional financial in harmony ratio (routine spending) before regional autonomy is smaller than the average of regional financial in harmony ratio (routine spending) after regional autonomy, and the average of regional financial in harmony ratio (development spending) before regional autonomy is greater than the average of regional financial in harmony ratio (development spending) after regional autonomy.

Suggestions for local governments in improving regional financial performance indicators through increased the own source revenue (PAD) should not burden the 
public with various charges. In addition, local governments should focus more on development spending in order to be able to achieve the goal of the implementation of regional autonomy that is to realize a just society prosperous in Indonesia. Suggestions for subsequent study to add various other regional financial performance indicators and add research sites in Indonesia for the benefits of more perfect study.

\section{REFERENCES}

Adi, P. H. 2012. Kemampuan Keuangan Daerah Dalam Era Otonomi Daerah dan Relevansinya dengan Pertumbuhan Ekonomi. Jurnal Studi Pembangunan, Vol. 21 (1): 1-19.

Aryanto, R. 2011. Analisis Kemandirian Keuangan daerah dan Pertumbuhan Ekonomi Kabupaten/Kota di Sumatra Selatan. Jurnal Ilmiah, Vol. 3 (2): 8699.

Azhar, M. 2012. Analisis Kinerja Keuangan Pemerintah Daerah Kabupaten/ Kota Sebelum dan Setelah Otonomi Daerah. Medan: Penerbit Universitas Sumatra Utara.

Badrudin, R. 2011. Effect of Fiscal Decentralization on Capital Expenditure, Growth, and Welfare. Economic Journal of Emerging Markets, Vol. 3 (3): 211-223.

Badrudin, R. 2012. Dampak Otonomi Daerah Terhadap Strategi Pembangunan Wilayah Kabupaten/Kota di Provinsi Jawa Tengah. Jurnal Akuntansi dan Manajemen, Vol. 23 (3): 165-185.

Dwijayanti, R., \& Rusherlistyanti. 2013. Analisis Perbandingan Kinerja Keuangan Pemerintah Provinsi SeIndonesia. Jurnal Ekonomi dan Bisnis, Vol. 12 (1): 43-66.
Enceng, Irianro, L., \& Purwaningdyah, M. 2012. Desentralisasi Fiskal Penerimaan Keuangan Daerah. Jurnal Ilmu Administrasi Negara, Vol. 12 (1): 61-73.

Mahmudi. 2010. Analisis Laporan Keuangan Pemerintah Daerah. Yogyakarta: UPP STIM YKPN.

Mustafa, B., \& Halim, A. 2009. Pengukuran Kinerja Dinas Pendapatan Daerah Provinsi Kalimantan Barat. Jurnal Aplikasi Manajemen, Vol. 7 (4): $792-$ 601.

Rasidah, \& Marsidah. 2009. Analisis Kinerja Keuangan Pemerintah Kabupaten Tapin Periode 2004-2008. Jurnal Ekonomi Pembangunan, Manajemen, dan Akuntansi, Vol 8 (2): 121-132.

Sularso, H., \& Restianto, Y. E. 2011. Pengaruh Kinerja Keuangan Terhadap Alokasi Belanja Modal dan Pertumbuhan Ekonomi Kabupaten/Kota di Jawa Tengah. Media Riset Akuntansi, Vol. 1 (2): 109-124.

Tangkilisan, H. 2005. Manajemen Publik. Jakarta: PT Grasiondo.

Taufik, M., Darwanis, \& Arfan, M. 2014. Analisis Perbedaan Kinerja Keuangan Pemerintah Daerah Periode Opini WDP dan Periode Opini WTP (Studi Pada Kabupaten/Kota di Provinsi Aceh tahun 2011-2012). Jurnal Akuntansi Pascasarjana Universitas Syiah Kuala, Vol. 5 (1): 104-113.

Wardana, H., \& Nasikh. 2013.Analisis Derajat Desentralisasi Fiskal Keuangan Daerah Sebelum dan Sesudah Pelaksanaan Kebijakan Otonomi Daerah di Kota Malang. Jurnal Ekonomi dan Studi Pembangunan, Vol. 5 (1): 31-38. 
